\title{
Effect of Lactobacillus sp. probiotics on intestinal histology, Escherichia coli in excreta and broiler performance
}

\author{
M.N. Hidayat ${ }^{1}$, R. Malaka ${ }^{2, *}$, L. Agustina ${ }^{2}$ and W. Pakiding ${ }^{2}$ \\ ${ }^{1}$ Faculty of Science and Technology, Alauddin State Islamic University of Makassar, \\ Gowa 92113, South Sulawesi - Indonesia \\ ${ }^{2}$ Faculty of Animal Science, Hasanuddin University, Makassar 90245, \\ South Sulawesi - Indonesia \\ *Corresponding E-mail: malaka_ag39@yahoo.co.id
}

Received March 28, 2018; Accepted April 15, 2018

\begin{abstract}
ABSTRAK
Penelitian dilakukan untuk mengetahui pengaruh Lactobacillus sp. terhadap penampilan histologi usus halus, jumlah bakteri Escherichia coli pada kinerja ayam broiler. Penelitian ini menggunakan rancangan acak lengkap yang terdiri dari 4 perlakuan dengan 5 ulangan, masing-masing ulangan menggunakan 16 ekor ayam broiler. Penelitian ini menggunakan probiotik Lactobacillus sp. 5,8 x $10^{7}$ $\mathrm{CFU} / \mathrm{mL}$ dicampur dalam air minum dan juga diberi konsentrat komersial secara ad libitum. Hasil penelitian menunjukkan bahwa perlakuan ini berpengaruh nyata $(\mathrm{P}<0,05)$ terhadap pertambahan berat badan, konversi ransum, dan berat akhir. Tidak ada perbedaan yang nyata antara konsumsi ransum dengan dosis Lactobacillus sp. 0 cc /hari, 1 cc/hari, 3 cc/hari, dan 5 cc/hari. Secara umum, perawatan probiotik 1, 3, dan $5 \mathrm{ml} /$ hari Lactobacillus sp. lebih baik pada tinggi vili, luas permukaan vili, berat badan, berat akhir, dan konversi pakan dibandingkan dengan kontrol. Perawatan dosis $3 \mathrm{ml} / \mathrm{d}\left(1.7 \times 10^{8}\right.$ CFU) adalah dosis terbaik dalam memberikan respon optimal terhadap histologi usus kecil, dan kinerja ayam pedaging. Perawatan $5 \mathrm{~mL} /$ hari memiliki jumlah Escherichia coli terendah dalam kotoran ayam pedaging. Disimpulkan bahwa Lactobacillus sp. dapat digunakan sebagai satu kandidat probiotik untuk ayam pedaging.

Kata kunci: Broiler, Escherichia coli, Histologi usus kecil, Lactobacillus, Probiotik
\end{abstract}

\section{ABSTRACT}

The study was conducted to determine the effect of Lactobacillus sp. in intestinal histology, total amount of Escherichia coli in broiler chicken excreta and broiler performance. Research has been conducted using a completely randomized design with 4 treatments and 5 replications utilize 15 chickens. Lactobacillus sp. $5.8 \times 10^{7} \mathrm{CFU} / \mathrm{mL}$ was mixed in drinking water and also feed commercial concentrates together ad libitum. The results showed that treatment had significant effect $(\mathrm{P}<0.05)$ on weight gain, ration conversion, and final weight. There was no difference $(\mathrm{P}>0.05)$ ration consumption on doses of Lactobacillus sp. treatment $0 \mathrm{~mL} /$ days, $1 \mathrm{ml} /$ days, $3 \mathrm{ml} /$ days, and $5 \mathrm{ml} /$ days. In general, the probiotic treatments of 1,3 , and $5 \mathrm{~mL} /$ days of lactobacillus sp. were better at villus height, villus surface area, weight gain, final weight, and feed conversion compared to control. Treatment a dose of $3 \mathrm{~mL} / \mathrm{d}$ $\left(1.7 \times 10^{8} \mathrm{CFU}\right)$ is the best dose in providing optimal response to histology of the small intestine, and broiler performance. Treatment $5 \mathrm{~mL} /$ days has the lowest amount of Escherichia coli in manure of broiler. In conclusion, Lactobacillus sp. can be used as one candidate probiotic for broiler.

Keywords: Broiler, Escherichia coli, histology of small intestine, Lactobacillus, Probiotics 


\section{INTRODUCTION}

Feed additives have an important role in the maintenance of broiler because it can contribute in producing good growth performance. Antibiotics is one of the feed additives that have long been used in the poultry industry to increase livestock productivity. However, lately, the use of antibiotics has become a serious concern for consumers related to food safety aspects. Because antibiotics may contribute to the emergence of some antibiotic-resistant pathogens and the presence of residues in livestock products. Therefore, several attempts have been made by scientists to look for other alternatives to reduce the use of antibiotics in poultry.

Utilization of microbes that are beneficial in the digestive tract of poultry is one alternative feed additive that continues to be developed to reduce the use of antibiotics. The microbial group is termed a probiotic. The group of lactic acid bacteria $(\mathrm{LAB})$ is a group of microbes that are much studied its use as a probiotic, because it is considered relatively safe. LAB have an important role in environmental, food and clinical microbiology. The bacterium is a normal microflora of the human digestive tract and livestock (Bhardwaj et al., 2011). Therefore LAB is one of the important microbial groups in the poultry digestive system (Musikasang et al., 2009).

Probiotics for livestock are generally developed to improve performance, health, and productivity performance. This can be achieved because probiotics can affect intestinal microbial populations, and intestinal morphology (Sugiharto, 2016). Probiotics work in the gastrointestinal tract by strengthening the function of intestinal mucosa against harmful substances. For example, enterotoxigenic produced by Escherichia coli, can result in considerable economic losses in poultry production (Kumar et al., 2004; Alonso et al., 2011). The results of the study of the addition of probiotics in the ration showed improved performance and ration efficiency in broiler (Awad et al., 2008). Probiotics have been shown to increase high villi jejunum and villi ileum (Chichlowski et al., 2007; Samli et al., 2007). The effects of probiotics on livestock and humans depend on strains, dosage, time use and viability of strains (Maassen et al., 2000: Isolauri et al., 2001).

Lactobacillus sp. is a lactic acid bacterium that is potentially developed as a probiotic candidate, because it has a high ability to stick to and grow in the intestinal epithelium of day old chick (DOC) (Fuller, 2008). However, this property cannot be generalized to all strains of probiotics because each strain has a specific effect. Therefore, research is needed to confirm the benefits of each lactic acid bacteria as a probiotic candidate. The purpose of this study was to determine the effect of Lactobacillus sp. in the histology of the small intestine, the amount of Escherichia coli in the stools and performance appearance of broiler chickens.

\section{MATERIALS AND METHODS}

\section{Research procedure}

A total of 80 strains of DOC broiler Cobb 500 were placed randomly in the experimental unit using a completely randomized design. There are 4 treatments consisting of 5 replications, each replication containing 16 DOC broiler. Probiotics used as a treatment contain Lactobacillus sp (5.8 $\left.\mathrm{x} 10^{7} \mathrm{CFU}\right)$ was isolated from broiler manure. Probiotic treatment dose consisted of $\mathrm{P} 1(0 \mathrm{~mL} / \mathrm{d})$, P2 $(1 \mathrm{~mL} / \mathrm{d})$, P3 $(3 \mathrm{~mL} / \mathrm{d})$, and P4 $(5 \mathrm{~mL} / \mathrm{d})$. Probiotic treatment is given for 35 days through drinking water. Rations and drinking water are given ad-libitum. The composition of starter and finisher rations is presented in Table 1.

\section{Samples of Intestinal Tissue}

Intestine samples from 20 broiler chickens were used in this study. Each part of the intestine was cut along 2 centimeters per section (duodenum, jejunum, and ileum), and each part of the small intestine is inserted into $10 \%$ formalin buffer. The small intestine surface (duodenum, jejunum, and ileum) of about $2 \mathrm{~mm}$ is then fed into formaldehyde for dehydration, and then fed into xylol for one hour for fixation, then coated with paraffin (infiltering process). After the tissue hardens, the tissue is then cut with a thickness of 3-4 $\mu \mathrm{m}$. Pieces were affixed to the glass object, then given paraffin and rehydration. Finally, the preparations on the glass of the object in the glue then covered with a glass cover for microscopic observation.

The villus height and surface area of the villus of duodenum, jejunum, and ileum were measured using a light microscope (objective magnification 0 times) and micrometer video (Zeiss AxioCam Erc 5s) in 10 fields of view on each preparation. The surface area of the villi is calculated according to the method $\mathrm{Iji}$ et al. 
Table 1. Ingredients and Chemical Composition of Basal Ration (\%)

\begin{tabular}{lcc} 
& \multicolumn{2}{c}{ Basal Ration } \\
\cline { 2 - 3 } Ingredient & Starter & Finisher \\
\hline Yellow corn & 53 & 60 \\
Rice bran & 6 & 5 \\
Soy meal & 28 & 21.2 \\
Meat and Bone Meal & 8 & 8.3 \\
vegetable oil & 3 & 3.3 \\
CaCO 3 & 0.80 & 1 \\
Dicalsium phosphate & 0.3 & 0.2 \\
DL-Methionin & 0.1 & 0.2 \\
L-Lysin & 0.3 & 0.5 \\
Vitamix & 0.5 & 0.3 \\
Calculated composition & & \\
Crude protein & 22.75 & 20.11 \\
Energy Metabolism (kcal/kg) & 3030 & 3105 \\
Fat & 6.7 & 6.9 \\
Crude fiber & 3.6 & 3.3 \\
Phosphor & 0.79 & 0.71 \\
Calcium & 1.43 & 1.43 \\
Lysine & 1.17 & 1.00 \\
Methionine & 0.35 & 0.32 \\
\hline
\end{tabular}

Eeach one kilogram contains Vitamin A 4000,000 IU, Vitamin D3 800,000 IU, Vitamin E 4,500 mg, Vit K3 450 mg, Vitamin B1 $450 \mathrm{mg}$, Vitamin B2 1,350 mg, Viamint B6 $480 \mathrm{mg}$, Vit B12 $6 \mathrm{mg}$, Ca-dP 2,400 mg, As folate 270 $\mathrm{mg}$, Nicotinic acid 7,200 mg, choline chloride 28,000 mg, DL-Met 28,000 mg, L-Lys 50,000 mg, Fe 8,500 mg, Cu $700 \mathrm{mg}, \mathrm{Mg} 18,500 \mathrm{mg}$, Zn 14,000 mg, Co $50 \mathrm{mg}$, I $70 \mathrm{mg}$, Se $35 \mathrm{mg}$, and antioxidants.

(2001).

\section{Enumeration of Escherichia coli}

Eosin Methylene Blue Agar (EMBA) 13.5 grams dissolved in $360 \mathrm{~mL}$ of aquades in Erlenmeyer. Buffer Pepton Water (BPW), 6.4 grams dissolved in $320 \mathrm{~mL}$ of aquades in Erlenmeyer, furthermore homogenized with a magnetic stirrer, and sterilized in the autoclave for 15 minutes at $121^{\circ} \mathrm{C}$. The EMBA and BPW medium was cooled to a temperature of about 40$45^{\circ} \mathrm{C}$, then pour into a $15 \mathrm{~mL}$ petri dish. While the media BPW in pour into the reaction tube each 10 $\mathrm{mL}$.

One gram of broiler excreta sample was weighed from each treatment $(\mathrm{P} 1, \mathrm{P} 2, \mathrm{P} 3$, and
P4), then feed into the test tube and add $10 \mathrm{~mL}$ BPW. Then homogenized with a stomacher to obtain a $10^{-1}$ dilution. Broiler stool samples from each treatment (P1, P2, P3, and P4) were diluted to $10^{-8}$ time dilution.

The number of colonies of Escherichia coli bacteria was calculated on the last three dilutions, i.e. $10-6,10-7,10-8$ in duplicate. One $\mathrm{mL}$ of the sample was placed in a petri dish, and then poured into sterile EMBA medium, incubated at $37^{\circ} \mathrm{C}$ for 18-24 hours. The amount of E. coli was calculated on the basis of colonies growing from 30-300.

\section{Broiler Performance Evaluation}

Feed intake and body weight gain was measured every week, while the final body weight 
was measured at the end of the study (35 day-old chicks). Feed conversion is calculated based on the ratio of feed consumption and body weight gain.

\section{Statistic analysis}

All data collected were subjected to analysis using one way ANOVA procedure of SPSS (SPSS version 21). The effect of treatment difference will compared using Duncan's multiple area tests at 5\% level $(\mathrm{P}<0.05)$.

\section{RESULTS AND DISCUSSION}

\section{Intestinal Histomorphology}

The results showed no significantly different between control (P1) and probiotic treatment (P2, $\mathrm{P} 3$, and P4) at height and surface area of villus of duodenum. Duodenum villus height was lowest in P1 (1.652 $\mathrm{mm})$ and the largest are in P4 (1.698 $\mathrm{mm})$. The value of the villus surface area was lowest in duodenum at P1 $(0.29 \mathrm{~mm})$ and the largest in treatment P3 and P4 (0.34 mm).

The villus height in jejunum showed a difference $(\mathrm{P}<0.05)$ between control $(\mathrm{P} 1)$ and probiotic treatment (P3 and $\mathrm{P} 4)$. Height of villus was smallest villus in the jejunum at P1 (1.354 $\mathrm{mm})$ and the largest in treatment P4 (1.493 $\mathrm{mm})$.
Similarly, the surface area of villus in jejunum showed a difference $(\mathrm{P}<0.05)$ between control (P1) and probiotic treatment (P3 and P4). The value of the villus surface area was lowest in jejunum at $\mathrm{P} 1(0.23 \mathrm{~mm})$ and the largest in treatment P3 $(0.29 \mathrm{~mm})$.

Furthermore, the height of villus in ileum showed a difference $(\mathrm{P}<0.05)$ between control $(\mathrm{P})$ with probiotic treatment (P3 and P4). Villus height was smallest in the ileum at P1 $(0.64 \mathrm{~mm})$ and the largest in treatment P3 $(0.76 \mathrm{~mm})$. Similarly, the surface area of villus in ileum showed a difference $(\mathrm{P}<0.05)$ between control (P1) and probiotic treatment (P3). The value of the villus surface area was lowest in ileum at P1 $(0.11 \mathrm{~mm})$ and the largest in treatment P3 (0.19 $\mathrm{mm})$. The data of the research results are presented in Table 2. According to the study by Yu et al. (2007) that ileum villus height of 6 week-old broiler by supplementation of Lactobacillus reuteri was $759 \pm 209 \mu \mathrm{m}(0.795 \pm 0.209 \mathrm{~mm})$. While in 35 day-old chick in this study have 0.76 $\pm 0.05 \mathrm{~mm}$ of height of villus. The intestinal epithelium of villus acts as a natural barrier against pathogenic bacteria and toxic substances that are present in the intestinal lumen (Pelicano et al., 2005), so that changes in the height of the villus are important in improving the performance

Table 2. The Histological Structure of the Broiler's Age of 35 Days

\begin{tabular}{|c|c|c|c|c|c|}
\hline \multirow{2}{*}{ The small intestine } & \multicolumn{4}{|c|}{ Treatment } & \multirow{2}{*}{ P-value } \\
\hline & P1 & $\mathrm{P} 2$ & P3 & $\mathrm{P} 4$ & \\
\hline \multicolumn{6}{|l|}{ Duodenum } \\
\hline Villus height (mm) & $1.652 \pm 0.03$ & $1.674 \pm 0.02$ & $1.695 \pm 0.03$ & $1.698 \pm 0.02$ & 0.20 \\
\hline Villus surface area $\left(\mathrm{mm}^{2}\right)$ & $0.29 \pm 0.10$ & $0.33 \pm 0.08$ & $0.34 \pm 0.13$ & $0.34 \pm 0.05$ & 0.35 \\
\hline \multicolumn{6}{|l|}{ Jejunum } \\
\hline Villus height (mm) & $1.354 \pm 0.17^{\mathrm{a}}$ & $1.405 \pm 0.12^{\mathrm{ab}}$ & $1.460 \pm 0.10^{\mathrm{b}}$ & $1.493 \pm 0.15^{\mathrm{b}}$ & 0.02 \\
\hline Villus surface area $\left(\mathrm{mm}^{2}\right)$ & $0.23 \pm 0.03^{\mathrm{a}}$ & $0.25 \pm 0.02^{\mathrm{ab}}$ & $0.29 \pm 0.02^{\mathrm{b}}$ & $0.28 \pm 0.02^{b}$ & 0.01 \\
\hline \multicolumn{6}{|l|}{ Ileum } \\
\hline Villus height (mm) & $0.64 \pm 0.03^{\mathrm{a}}$ & $0.65 \pm 0.01^{\mathrm{a}}$ & $0.76 \pm 0.05^{\mathrm{b}}$ & $0.74 \pm 0.01^{b}$ & 0.00 \\
\hline $\begin{array}{l}\text { Villus surface area } \\
\left(\mathrm{mm}^{2}\right)\end{array}$ & $0.11 \pm 0.05^{\mathrm{a}}$ & $0.12 \pm 0.01^{\mathrm{ab}}$ & $0.19 \pm 0.06^{\mathrm{c}}$ & $0.16 \pm 0.02^{\mathrm{ab}}$ & 0.01 \\
\hline
\end{tabular}

a,b,c Mean value on the same row with different superscripts shows significant differences $(\mathrm{P}<0.05)$ 
of broiler chickens.

Probiotic treatments (P2, P3, and P4) tend to have longer villus and wider surfaces in all parts of the small intestine (duodenum, jejunum, and ileum) compared with treatment of P1 (control). The mean villus height in the duodenum is longer than in the jejunum and ileum at all treatments (P1, P2, P3, and P4). Likewise, the area of the villus in the duodenum is wider than in the jejunum and ileum in all treatments. The results of this study are in line with previous studies by (Chichlowski et al., 2007; Samli et al., 2007) with Enterococcus probiotic treatment given in broiler ration can increase the height of villus in jejunum and ileum.

The digestive tract is considered to be the most limiting factor in broiler performance. Therefore, the digestive tract health condition is an important part must be maintained because it has an important role in the process of digestion and absorption. There is a strong correlation between histological changes of intestinal villus to body weight in poultry (Awad et al., 2006). The amount of nutrient absorption will be great if the surface area of the villus is wider (Johnson and Gee, 1986). the height of the villus (Adibmoradi et al., 2006) and the surface area of the villus (Caspary, 1992; Awad et al., 2006).The density and size of villus in the small intestine is the best measurement to show the rate of absorption change in the villus surface area (Ferrer et al., 1995). This is due to the association with poultry absorption capacity (Silva et al., 2007).

\section{Population Escherichia coli in Broiler Excreta}

The results showed treatment significantly $(\mathrm{P}<0.05)$ to the amount of Escherichia coli in broiler feces. There is a significantly different $(\mathrm{P}<0.05)$ in the number of Escherichia coli in treatment $\mathrm{P} 1, \mathrm{P} 2$, and $\mathrm{P} 3$ with $\mathrm{P} 4$ treatment. The total number count of Escherichia coli was largest at treatment P1 $(\log 7.65 \mathrm{CFU} / \mathrm{g}$ and lowest on treatment P4 $(\log 7.08 \mathrm{CFU} / \mathrm{g})$. The data of the research results are presented in Figure 1. Escherichia coli is a member of the normal microbiota in poultry intestine (Coura et al., 2017). But if this bacterial population is too high in intersine it can be become pathogenic.

Among the pathogenic bacteria that can grow and attach to the surface of the intestinal villi is Escherichia coli (Edelman et al., 2003). The results of this study showed that the administration of Lactobacillus sp. (P2, P3, and P4) tended to reduce the number of Escherichia coli population in broiler feces compared to P1 (control). The results of this study are in line with research (Hassan et al., 2014) that birds feed tested Probiotic (Enterococcus faecium, Bacillus subtilis, dan Saccharomyces cerevisiae) supplemented diet had significant less Escherchia coli population in the intestine compared to the control birds.

The ability of Lactobacillus sp. to decrease Escherichia coli will provide benefits for the condition of the digestive tract. Lactic Acid Bacteria (BAL) is a class of beneficial microorganisms with non-toxic properties to its host and capable of producing antimicrobial

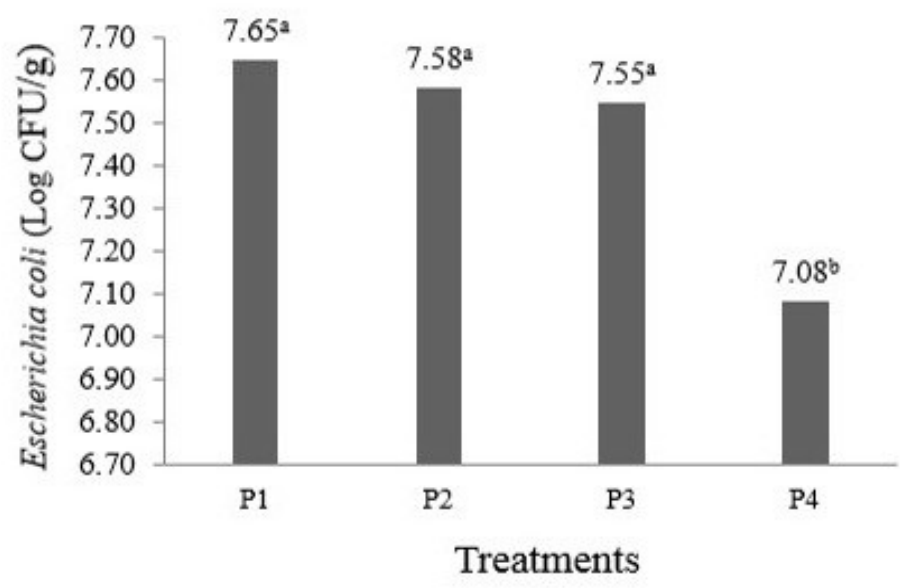

Figure 1. Number of Escherichia coli ( Log CFU/g) in Broiler Feces Age of 35 Days. ${ }^{\text {a,b }}$ Mean value with different superscripts shows significant differences $(\mathrm{P}<0.05)$. 
compounds that can kill pathogenic bacteria (Klaenhammer et al., 2005). Antimicrobial compounds produced by BAL (Lactobacillus) such as, organic acids, hydrogen peroxide, diacetyl and bacteriocin (Abdelbasset and Djamila, 2008). They are a major part of the LAB group (including Lactobacillus, Lactococcus, Enterococcus, Oenococcus, Pediococcus, Streptococcus and Leuconostocspecies) that can convert hexose sugars to lactic acid thus producing an acid environment which inhibits the growth of several species of harmful bacteria (Makarova et al., 2006).

The balance of microflora between pathogens and beneficial must be maintained, one of them with the provision of probiotics (Sugiharto et al., 2017a; Suhigarto et al., 2017b). According to (Fuller, 1989) probiotics is a living microorganism that serves as a feed additive that gives the beneficial effect of its host by improving the balance of bacteria in the intestine. Furthermore (Dalloul et al., 2003; Vilà et al., 2009; Mountzouris et al., 2010; Yang et al., 2009; Hassan et al., 2014) stated that probiotics can maintain useful intestinal microflora, increase resistance to enteric pathogens such as Escherichia coli, Salmonella and Campylobacter species, produce a healthy gastrointestinal environment and better bowel function.

\section{Growth Performance}

The result showed that the treatment significant effect $(\mathrm{P}<0.05)$ on body weight gain, feed conversion, and final body weight. There was no difference feed consumption on treatment P1, P2, P3, and P4. The treatment P3 (2.370 g) was highest on feed intake and lowest on treatment P2 $(2,308 \mathrm{~g})$. The weight gain, final body weight, and feed conversion were significantly different $(\mathrm{P}<0.05)$ between treatments. Body weight gain and final body weight in the treatment of P2, P3, and P4 was higher than P1 (control). Body weight gain and final body weight was highest on treatment P3 (40.43 g and 1,467 g) and lowest on treatment P1 (36.94 g and 1, $330 \mathrm{~g})$. Feed conversion in treatment P2, P3, and P4 lower than P1 (control). The feed conversion was highest in treatment P1 (1.82) and lowest in treatment P3 (1.67). The data of the research results are presented in Table 3. Probiotic treatment in this study was not significantly different on feed intake. The feed intake on probiotic treatments (P2, P3, and P4), tends to increase as the treatment dose increases. This may be because the feed used have the same ingredients and nutritional composition. The results of this study was accordance with the statement (Willis et al., 2007), that the provision of probiotics does not affect the feed intake.

Probiotics are living organisms given to livestock that also need nutritional needs for growth and development in the digestive tract. Increased feed intake on treatment P2, P3 and P4 (Table 3) in this study may be due to reduced broiler requirements, as some nutrients are used by probiotics for their energy needs. According to Apajalahti et al. (2004), energy requirements for reproduction and bacterial growth in the gastrointestinal tract are mostly obtained from nutrients that are resistant to gastrointestinal attacks or absorbed very slowly, so that livestock will compete with bacteria for the utilization. Small intestinal bacterial may use 10 to $20 \%$ carbohydrates and amino acids that can also be exploited by the livestock body.

Body weight gain, final body weight, and

Table 3. Feed Consumption, Body Weight Gain, Final Body Weight, and Feed Conversion at Broiler Age of 35 Days

\begin{tabular}{lccccc}
\hline Parameter & \multicolumn{5}{c}{ Probiotic (mL/day) } \\
\cline { 2 - 6 } & P1 & P2 & P3 & P4 & P-Value \\
\hline Feed intake (g/head) & 2.354 & 2.308 & 2.370 & 2.367 & 0.33 \\
Body weight gain (g/head/day) & $36.94^{\mathrm{a}}$ & $38.54^{\mathrm{ab}}$ & $40.43^{\mathrm{b}}$ & $40.20^{\mathrm{b}}$ & 0.01 \\
Final body weight (g) & $1,430^{\mathrm{a}}$ & $1,445^{\mathrm{ab}}$ & $1,567^{\mathrm{b}}$ & $1,554^{\mathrm{b}}$ & 0.05 \\
Feed conversion & $1.82^{\mathrm{a}}$ & $1.71^{\mathrm{ab}}$ & $1.67^{\mathrm{b}}$ & $1.68^{\mathrm{b}}$ & 0.01 \\
\hline
\end{tabular}

${ }^{a, b}$ Mean value on the same row with different superscripts shows significantly different $(\mathrm{P}<0.05)$. 
ration conversion on probiotic treatment $(\mathrm{P} 2, \mathrm{P} 3$, and $\mathrm{P} 4$ ) were better than $\mathrm{P} 1$ treatment (control). The results of this study were consistent with the assertion of (Alkhalf et al., 2010), that probiotic supplementation showed a significant increase in body weight compared with the control group, at the same age. Further research results Cao et al. (2013), found that a broiler diet supplement with one Lactobacillus strain significantly improved body weight gain and final body weight compared with controls. However, Bitterncourt et al. (2011) state that probiotics (containing bacteria Lactobacillus acidophilus, Streptococcus faecium and Bifidobacterium bifidum) have no significant effect on broiler performance. Similarly, the results of the study of Olnood et al. (2015), which provided probiotics through rations, drinking water, and spraying on litter did not significantly affect the performance of broiler growth.

Feed conversion in probiotic treatment $(\mathrm{P} 2$, $\mathrm{P} 3$, and $\mathrm{P} 4$ ) is better than the P1 (control). The increasing dose of probiotics in this studies tends to decrease the value of feed conversion. This shows that probiotics can improve feed efficiency in broiler. Treatment of P3 with a dose of 3 $\mathrm{mL} /$ day $\left(1.7 \times 10^{8} \mathrm{CFU}\right)$ is the best dose in providing an optimum response to the value of feed conversion. According to Huang et al., (2004), the provision of Lactobacillus-based probiotics in high doses does not always result in better performance, since each probiotic strain will provide an optimum response at a given dose. Meanwhile, according to Mountzouris et al. (2010), there is no consistent conclusion to be drawn about the effect of the rate of probiotics on growth performance because of the contradictory results found in the literature, each probiotic strain will work optimally depending on the strain concentration of each tested probiotic Shim et al. (2010), probiotics given daily in livestock can be useful if they contain microorganisms $10^{7}$ to $10^{9}$.

\section{CONCLUSIONS}

Treatment of Lactobacillus sp. probiotics has a significant effect on the villus height in the jejunum and ileum, the villus area in jejunum and ileum, the number of Escherichia coli and weight gain, final weight, and feed conversion. The best dose of probiotic treatment is $\mathrm{P} 3(3 \mathrm{~mL} /$ day $)$ with a bacterial content of $2.9 \times 10^{8}$ CFU. Lactobacillus sp. which is used as a probiotic in this study provides a positive response to the histology of the small intestine, decreasing the amount of Escherichia coli in broiler chicken manure and improves broiler performance.

\section{REFERENCES}

Abdelbasset, M. and K. Djamila. 2008. Antimicrobial activity of autochthonous lactic acid bacteria isolated from Algerian traditional fermented milk "Raïb." Afr. J. Biotechnol. 7(16):2908-2914

Adibmoradi, M., B. Navidshad, J. Seifdavati and M. Royan. 2006. Effect of Dietary Garlic Meal on Histological Structure of Small Intestine in Broiler Chickens. J. Poult. Sci. 43(4):378-383.

Alkhalf, A., M. Alhaj and I. Al-homidan. 2010. Influence of probiotic supplementation on blood parameters and growth performance in broiler chickens. Saudi J. Biol. Sci. 17(3): 219-225.

Alonso, M., N. Padola, A. Parma and P. Lucchesi. 2011. Enteropathogenic Escherichia coli contamination at different stages of the chicken slaughtering process. Poult. Sci. 90(11):2638-2641.

Apajalahti, J., A. Kettunen and H. Graham. 2004. Characteristics of the gastrointestinal microbial communities, with special reference to the chicken. World39s Poult. Sci. J. 60(2):223-232.

Awad, W., K. Ghareeb and J. Böhm. 2008. Intestinal Structure and Function of Broiler Chickens on Diets Supplemented with a Synbiotic Containing Enterococcus faecium and Oligosaccharides. Int. J. Mol. Sci. 9(11):2205-2216.

Awad, W.A., J. Böhm, E. Razzazi-Fazeli, K. Ghareeb and J. Zentek. 2006. Effect of addition of a probiotic microorganism to broiler diets contaminated with deoxynivalenol on performance and histological alterations of intestinal villi of broiler chickens. Poult. Sci. 85(6): 974-979.

Bhardwaj, A., G. Kaur, H. Gupta, S.Vij and R. Malik. 2011. Interspecies diversity, safety and probiotic potential of bacteriocinogenic Enterococcus faecium isolated from dairy food and human faeces. World J Microb Biotechnol 27(3):591-602

Bitterncourt, L.C., C.C. Silva, P.D.S.R. da Garcia, DCZ Donato, R. Albuquerque and L.F. de, Araújo. 2011. Influence of a probiotic on broiler performance. Rev. Bras. Zootec. 40(12):2739-2743. 
Cao, G.T., X.F. Zeng, A.G. Chen, L. Zhou, L. Zhang, Y.P. Xiao and C.M. Yang. 2013. Effects of a probiotic, Enterococcus faecium, on growth performance, intestinal morphology, immune response, and cecal microflora in broiler chickens challenged with Escherichia coli K88. Poult. Sci. 92(11):2949-2955.

Caspary, W.F. 1992. Physiology and pathophysiology of intestinal absorption. Am. J. Clin. Nutr. 55, 299S-308S.

Chichlowski, M., W.J Croom, F.W. Edens, B.W. McBride, R. Qiu, C.C. Chiang, L.R. Daniel, G.B. Havenstein and M.D. Koci. 2007. Microarchitecture and spatial relationship between bacteria and ileal, cecal, and colonic epithelium in chicks fed a direct-fed microbial, PrimaLac, and salinomycin. Poult. Sci. 86(6):1121-1132.

Coura, F.M., A.D. Soraia A. Diniz, M.X. Silva, T.L.M. Arcebismo, S. Minharro, A.C.F. Feitisa, A.P. Lage, T. Knobl, J.M.S. Mussi and M.B. Heinemann. 2017. Phylogenic group of Escherichia coli isolates from broilers in Brazilian poultry slaughterhouse. The Scientific World Journal.

Dalloul, R.A., H.S. Lillehoj, T.A. Shellem and J.A. Doerr. 2003. Enhanced mucosal immunity against Eimeria acervulina in broilers fed a Lactobacillus-based probiotic. Poult. Sci. 82(1): 62-66.

Edelman, S., S. Leskelä, E. Ron, J. Apajalahti and T.K. Korhonen. 2003. In vitro adhesion of an avian pathogenic Escherichia coli $\mathrm{O} 78$ strain to surfaces of the chicken intestinal tract and to ileal mucus. Vet. Microbiol. 91(1): 41-56.

Ferrer, R., J.M. Planas and M. Moretó.1995. Cell apical surface area in enterocytes from chicken small and large intestine during development. Poult. Sci. 74(12):1995-2002.

Fuller, R. 2008. Ecological Studies on the Lactobacillus Flora Associated with the Crop Epithelium of the Fowl. J. Appl. Microbiol. 36(1):131-139.

Fuller, R. 1989. Probiotics in man and animal. J Appl Bacteriol 66(5): 365-378.

Hassan, H.M.A., A. F. Youssef, E. El- Daly, N.R. Abd el-Azeem R.E. Hassan and M.A. Mohamed. 2014. Performance, Caecum Bacterial Count and Ileum Histology of Broilers Fed Different Direct-Fed Microbials. J. Poultry Science 8(4): 106-114

Huang, M.K., Y.J. Choi, R. Houde, J.W. Lee, B. Lee and X. Zhao. 2004. Effects of Lactobacilli and an acidophilic fungus on the production performance and immune responses in broiler chickens. Poult. Sci. 83(5):788-795.

Iji, P.A., A. Saki and D.R. Tivey. 2001. Body and intestinal growth of broiler chicks on a commercial starter diet. 1. Intestinal weight and mucosal development. Br. Poult. Sci. 42(4):505-513.

Isolauri, E., Y. Sütas, P. Kankaanpää, H. Arvilommi and S. Salminen. 2001. Probiotics: effects on immunity. Am. J. Clin. Nutr. 73(2):444S-450S 